\title{
国/ QUEEN'S UNIVERSITY BELFAST

\section{Influence of potassium supply on growth and uptake of nitrogen, phosphorus, and potassium by three ectomycorrhizal fungal isolates in vitro}

Yuan, L., Huang, J. G., Christie, P., \& Li, X. L. (2005). Influence of potassium supply on growth and uptake of nitrogen, phosphorus, and potassium by three ectomycorrhizal fungal isolates in vitro. Journal of Plant Nutrition, 28(2), 271-284. https://doi.org/10.1081/PLN-200047614

Published in:

Journal of Plant Nutrition

Queen's University Belfast - Research Portal:

Link to publication record in Queen's University Belfast Research Portal

\section{General rights}

Copyright for the publications made accessible via the Queen's University Belfast Research Portal is retained by the author(s) and / or other copyright owners and it is a condition of accessing these publications that users recognise and abide by the legal requirements associated with these rights.

Take down policy

The Research Portal is Queen's institutional repository that provides access to Queen's research output. Every effort has been made to ensure that content in the Research Portal does not infringe any person's rights, or applicable UK laws. If you discover content in the Research Portal that you believe breaches copyright or violates any law, please contact openaccess@qub.ac.uk. 


\title{
Influence of Potassium Supply on Growth and Uptake of Nitrogen, Phosphorus, and Potassium by Three Ectomycorrhizal Fungal Isolates In Vitro
}

\author{
Ling Yuan, ${ }^{1,2}$ Jianguo Huang, ${ }^{2}$ Peter Christie,,${ }^{1,3}$ and Xiaolin $\mathrm{Li}^{1}$ \\ ${ }^{1}$ Department of Plant Nutrition, China Agricultural University, \\ Key Laboratory of Plant-Soil Interactions, Ministry of Education, \\ and Key Laboratory of Plant Nutrition, Ministry of Agriculture, Beijing China \\ ${ }^{2}$ College of Resources and Environment, Southwest Agricultural University, \\ Chongqing, China \\ ${ }^{3}$ Agricultural and Environmental Science Department, Queen's University Belfast, \\ Belfast, UK
}

\begin{abstract}
Three ectomycorrhizal fungal isolates, Cenococcum geophilum SIV, a putative isolate of Pisolithus microcarpus and a Pisolithus sp., were cultured in vitro without potassium (K) and with three levels of $\mathrm{K}$ supply $\left(\right.$ as $\mathrm{K}_{2} \mathrm{SO}_{4}$ ). Some growth stimulation by $\mathrm{K}$ was observed among the fungi. Potassium in the liquid medium led to increased concentrations of nitrogen $(\mathrm{N})$ and $\mathrm{K}$ in the fungi compared to K-free controls, and to higher phosphorus (P) concentrations in Pisolithus sp., but lower $\mathrm{P}$ in C. geophilum SIV. In a second experiment, the $\mathrm{K}$ influx rates of the fungi from external solutions followed Michaelis-Menten kinetics, indicating that $\mathrm{K}$ influx was an active process. Mycorrhizal fungi showed quite small $C_{\min }$ values for $\mathrm{K}$ influx, ranging from 2.12 to $5.39 \mu \mathrm{mol} \mathrm{L}^{-1}$, in relation to $\mathrm{K}$ concentrations in the external solution. Such low $C_{\min }$ values might allow the external hyphae to extract $\mathrm{K}$ efficiently from K-deficient soils. Furthermore, the fungi had low $K_{m}$ values for K uptake $\left(<14.85 \mu \mathrm{mol} \mathrm{L}^{-1}\right)$, indicating high affinities and efficiencies of K carriers. Both Pisolithus sp. and P. microcarpus exhibited similar $C_{\min }$ and $K_{m}$ values but were different from $C$. geophilum SIV. Furthermore, $I_{\max }$ values varied significantly among the fungi, ranging from 9.60 to $21.63 \mu \mathrm{mol} \mathrm{g}^{-1} \mathrm{DM} \mathrm{h}^{-1}$, perhaps due to variation in the intracellular $\mathrm{K}$ concentrations in the ectomycorrhizal fungi.
\end{abstract}

Received 6 January 2004; accepted 1 April 2004.

Address correspondence to X. L. Li, Department of Plant Nutrition, College of Agricultural Resources and Environmental Sciences, China Agricultural University, 2 Yuan Ming Yuan West Rd., Beijing 100094, China. E-mail: lixl@cau.edu.cn. 
Keywords: ectomycorrhizal fungi, K uptake kinetics, nutrient interactions, nutrient uptake

\section{INTRODUCTION}

Tropical and subtropical forest and plantation soils are often potassium (K)deficient and improvement of $\mathrm{K}$ nutrition could promote tree growth in these conditions. Ectomycorrhizal fungal colonization can aid both growth and nutrient absorption by trees (Smith and Read, 1997). External hyphae on mycorrhizal roots may access soil $\mathrm{K}$ reserves not directly available to most plants (Wallander, 2000; Wallander and Wickman, 1999) and thus enhance K uptake by the host plants (Huang and Lapeyrie, 1996). Release of fungal protons and oxalates, which is strongly promoted by simultaneous depletion of available $\mathrm{K}$ and magnesium (Mg) (Paris et al., 1995, 1996), may provide mechanisms for the fungi to replace interlayer $\mathrm{K}$ and cause weathering of $\mathrm{K}$-containing minerals in soils (Lapeyrie et al., 1987; Lapeyrie, 1988; Landeweert et al., 2002). This hypothesis has been partly supported by soil analysis showing that Douglas fir seedlings infected by the ectomycorrhizal fungus Laccaria bicolor S238N extracted HF$\mathrm{HClO}_{4}$-digestible $\mathrm{K}$ in a sequential extraction procedure that started with water, ammonium acetate, and $\mathrm{HCl}$ as extractants (Huang and Lapeyrie, 1996). Even so, there is still no direct evidence for the exploitation by ectomycorrhizas of $\mathrm{K}$ in soil pools, especially those unavailable to non-mycorrhizal plants. Analysis of $\mathrm{K}$ concentrations in plant tissues has also failed to demonstrate unequivocally the involvement of mycorrhizas in mobilization and plant uptake of soil $\mathrm{K}$. There is some evidence of increased $\mathrm{K}$ uptake by trees from soil following mycorrhizal inoculation, but in other cases $\mathrm{K}$ has been found at lower concentrations in mycorrhizal plant tissues as compared with uninoculated controls (Smith and Read, 1997; Bowen, 1973).

Hyphal $\mathrm{K}$ acquisition by mycorrhizal spruce roots was significant and contributed a minimum of 5\%-6\% of total plant $\mathrm{K}$ uptake, indicating an important role of ectomycorrhizal mycelium in K nutrition of host plants (Jentschke et al., 2001). The favorable effects of ectomycorrhizal fungi on plant nutrition have traditionally been attributed to the capacity of extraradical mycelium to absorb dissolved nutrients from the soil solution (Smith and Read, 1997). Kinetic parameters of ion uptake $\left(K_{m}, I_{\max }\right.$, and $\left.C_{\min }\right)$ may, to some extent, govern the ion uptake by mycorrhizal plants and fungi from solutions (Chalot et al., 2002). Based on work using isotopic tracers, ${ }^{41} \mathrm{~K}$ influx may be carried out by active processes and variation in the intensity of apoplastic movement of the nutrient can be observed depending on the fungal partners (Kuhn et al., 2000; Bucking and Heyser, 2000). $K_{m}$ values for K absorption by Laccaria bicolor, Lactarius rufus, and Lactarius hepaticus were found to be 24,18 , and $96 \mu \mathrm{mol} \mathrm{L}^{-1}$, respectively (Jongbloed et al., 1991), indicating variable affinities of K carriers and channels on fungal membranes. These differences between more efficient 
and less efficient mycorrhizal strains might lead to variation in the capacity of host plants to extract $\mathrm{K}$ from soil solutions. In addition, non-mycorrhizal seedlings of Pinus sylvestris and seedlings colonized by Paxillus involutus and Suillus variegatus were all able to access $\mathrm{K}$ in biotite, leading to stimulated growth and $\mathrm{K}$ uptake relative to $\mathrm{K}$-free controls. However, when microcline was the K source, growth depression was induced in the seedlings (with the exception of those colonized by $P$. involutus, in which tree growth was increased), suggest that more Kwas extracted from microcline by seedlings colonized by P. involutus (Wallander and Wickman, 1999). Co-translocation of a limiting element $(\mathrm{P})$ occurred with non-limiting nutrients $(\mathrm{N}, \mathrm{K}$, and $\mathrm{Ca}$ ) by a $P$. involutus isolate (Jentschke et al., 2001). Smith et al. (1981) observed elevated concentrations of K in shoots of endomycorrhizal Trifolium subterraneum when plants were grown in P-deficient soils. If sufficient $\mathrm{P}$ was supplied to the soil to remove any mycorrhizal growth responses, then $\mathrm{K}$ concentrations in mycorrhizal and non-mycorrhizal plants were very similar.

Clearly, generalizations concerning involvement of ectomycorrhizal fungi in Kuptake by host trees cannot be made with confidence at present. The understanding of the roles of mycorrhizal fungi in the Knutrition of trees is complicated by various properties of fungal $\mathrm{K}$ uptake from soil solutions and interferences in the field, especially complex interactions among nutrients in soil solutions. Moreover, interactions in nutrient uptake by higher plants and yeast have been studied in some detail (Borst-Pauwels, 1981; Marschner, 1995), but information on this aspect is quite scarce for ectomycorrhizal fungi. The objective of the present experiment was to elucidate the effects of Ksupply on the growth and N, P, and K uptake by ectomycorrhizal fungal isolates in liquid culture. The kinetics of $\mathrm{K}$ uptake by the fungi were also determined to investigate the efficiency of fungal $\mathrm{K}$ uptake from the culture solutions.

\section{MATERIALS AND METHODS}

\section{Fungal Material}

The three ectomycorrhizal fungi used in the experiments, namely Cenococcum geophilum SIV, a putative isolate of Pisolithus microcarpus formerly referred to as P. tinctorius 441 (Martin et al., 2002) and Pisolithus sp. (previously P. tinctorius 2144) were provided by Dr. Frédéric Lapeyrie of the Centre de Recherches Forestières de Nancy in France. The putative isolate of P. microcarpus was originally isolated in Brazil, and Pisolithus sp. in Australia (both from mycorrhizal Eucalyptus spp.); C. geophilum SIV was originally isolated from spruce mycorrhizas in Europe. The three fungi were maintained in culture by successive transfer on Pachlewski agar medium in the Microbiology Laboratory, Southwest Agricultural University, Chongqing, China. Mycelia for inoculation were grown on Pachlewski agar medium for 3 to 4 weeks. The medium contained 
ammonium tartrate $0.5, \mathrm{KH}_{2} \mathrm{PO}_{4} 1.0, \mathrm{MgSO}_{4} 0.5$, glucose 20, maltose 5.0, vita$\min \mathrm{B}_{1} 0.1$, and agar $20 \mathrm{~g} \mathrm{~L}^{-1}$, respectively, and $1 \mathrm{ml} \mathrm{L}^{-1}$ microelement solution [1 $\mathrm{L}$ microelement solution contained $\mathrm{H}_{3} \mathrm{BO}_{3} 8.45, \mathrm{MnSO}_{4} 5, \mathrm{FeSO}_{4} 6, \mathrm{CuSO}_{4}$ $0.625, \mathrm{ZnCl}_{2} 2.27$ and $\left(\mathrm{NH}_{4}\right)_{2} \mathrm{MoO}_{4} 0.27 \mathrm{mg}$, respectively].

\section{Experiment 1}

Experiment 1 was carried out to study the effects of $\mathrm{K}$ on fungal growth and uptake of $\mathrm{N}, \mathrm{P}$, and $\mathrm{K}$. The $\mathrm{KH}_{2} \mathrm{PO}_{4}$ in Pachlewski liquid medium was replaced by $\mathrm{NaH}_{2} \mathrm{PO}_{4}$ to give equivalent $\mathrm{P}$ and the experimental treatments were established by adding $\mathrm{K}_{2} \mathrm{SO}_{4}$ to the liquid medium at the following concentrations 0 , $0.13,0.65$, and $3.25 \mathrm{~g} \mathrm{~L}^{-1}$. The standard $\mathrm{K}$ concentration in Pachlewski medium was equivalent to $0.65 \mathrm{~g} \mathrm{~K}_{2} \mathrm{SO}_{4} \mathrm{~L}^{-1}$. These concentrations are referred to as no $\mathrm{K}$ and low, medium, and high $\mathrm{K}$, respectively, unless otherwise stated. Pachlewski liquid medium $(20 \mathrm{~mL})$ was transferred to a $250 \mathrm{ml}$ Erlenmeyer flask and steam-sterilized at $121^{\circ} \mathrm{C}$ for 30 minutes. Each flask was inoculated with one $6 \mathrm{~mm}$-diameter plug of mycelium and incubated without agitation for 3 weeks at $25 \pm 1{ }^{\circ} \mathrm{C}$ in the dark.

The fungal mycelium was harvested, washed free of culture medium with deionized water, and oven dried at $80 \pm 2^{\circ} \mathrm{C}$ for $8 \mathrm{~h}$. The dry weights of fungal mycelia were recorded and the concentrations of $\mathrm{N}, \mathrm{P}$, and $\mathrm{K}$ in the dry samples were determined by standard methods (indophenol blue and molybdenum blue methods followed by colorimetry and flame photometry, respectively) after digestion in $\mathrm{H}_{2} \mathrm{O}_{2}-\mathrm{H}_{2} \mathrm{SO}_{4}$ solution.

\section{Experiment 2}

Experiment 2 was conducted to determine the kinetics of $\mathrm{K}$ uptake by the ectomycorrhizal fungi. Mycelia were cultured without agitation in Pachlewski liquid medium in which $90 \%$ of $\mathrm{K}$ was omitted by substituting $\mathrm{KH}_{2} \mathrm{PO}_{4}$ with $\mathrm{NaH}_{2} \mathrm{PO}_{4}$. The cultures were grown in $200 \mathrm{ml}$ beakers containing $20 \mathrm{~mL}$ sterilized liquid medium inoculated with a $6 \mathrm{~mm}$-diameter mycelial plug. The cultures grew for 2 weeks at $25 \pm 1^{\circ} \mathrm{C}$ in the dark because preliminary tests showed that the highest rates of $\mathrm{K}$ influx occurred after 2 weeks (data not presented). Three fungal colonies from each culture were carefully transferred to an $8 \mathrm{~cm}$-diameter Petri dish. Sterilized solution containing $100 \mu \mathrm{mol} \mathrm{L}^{-1} \mathrm{CaCl}_{2}$ and $0.1 \%$ glucose (w/v) buffered with $5 \mathrm{mmol} \mathrm{L}^{-1}$ citric acid/Tris at $\mathrm{pH} 4.5$ was added and then removed slowly by pipette to avoid damage to the fungal hyphae. This procedure was repeated several times to completely replace the liquid culture medium in contact with the surface of the fungal hyphae. The colonies were incubated in the Petri dish containing $40 \mathrm{~mL}$ of wash solution for $48 \mathrm{~h}$ at $25 \pm 1^{\circ} \mathrm{C}$ in the dark. 
The incubation solution was replaced with $40 \mathrm{~mL}$ solution for $\mathrm{K}$ absorption (KCl, $75 \mu \mathrm{mol} \mathrm{L}^{-1} ; \mathrm{CaCl}_{2}, 100 \mu \mathrm{mol} \mathrm{L}{ }^{-1} ; \mathrm{pH}$ 5.8). At regular time intervals $(2,5,10,20,40,60,120$, and $180 \mathrm{~min})$, the $\mathrm{K}$ concentration in the solutions was measured using a $\mathrm{K}$ microprobe (Jiangsu Instrument Co., Taixian, China). Temperature continued to be maintained at $25 \pm 1{ }^{\circ} \mathrm{C}$ during the period of $\mathrm{K}$ uptake in the dark.

At the end of the $\mathrm{K}$ absorption period, the dry weights of the fungal colonies in each Petri dish were recorded to calculate the amount $\left(\mathrm{mg} \mathrm{g}^{-1} \mathrm{DM}\right)$ and rate ( $\mu \mathrm{mol} \mathrm{g}^{-1} \mathrm{DM} \mathrm{min}^{-1}$ ) of $\mathrm{K}$ absorption by the ectomycorrhizal fungi according to $\mathrm{K}$ depletion of the solutions.

\section{Data Analysis}

Fungal growth rates in Experiment 1 were subjected to two-way analysis of variance with replication using the SAS package (Statsoft, SAS Institute Inc., Cary, NC, USA). Multiple regression equations were derived to fit the K uptake kinetics in Experiment 2 using SigmaPlot 2000 for Windows (SPSS Inc., USA).

\section{RESULTS}

\section{Effects of Potassium Concentration in Culture Medium on Growth of Ectomycorrhizal Fungi}

As shown in Figure 1, the three fungi varied greatly in growth rate in the sequence $C$. geophilum SIV $>$ Pisolithus $\mathrm{sp}$. $>$ P. microcarpus. The mean growth rates ranged widely from 0.43 to $2.92 \mathrm{mg} \mathrm{DM} \mathrm{day}{ }^{-1}$. The K concentration in the culture medium strongly influenced the growth of the ectomycorrhizal fungi, but the highly significant interaction term reflects the different patterns of influence. Thus, C. geophilum SIV showed much higher growth rates when $\mathrm{K}$ was applied compared with the control, with a smaller increase as $\mathrm{K}$ concentration increased. In contrast, growth of Pisolithus sp. increased only at the highest $\mathrm{K}$ concentration studied and the growth rate of $P$. microcarpus was almost unaffected by K supply.

\section{Effects of Potassium Concentration in Culture Medium on Nitrogen, Phosphorus, and Potassium in Ectomycorrhizal Fungi}

The lowest and least variable $\mathrm{N}$ concentrations and uptake values of all three fungi were observed in the zero-K controls. When $\mathrm{K}$ was added to the medium there was a marked increase in fungal $\mathrm{N}$ concentration and uptake that varied among the three fungi (Fig. 2). The presence of $\mathrm{K}$ in the medium increased 


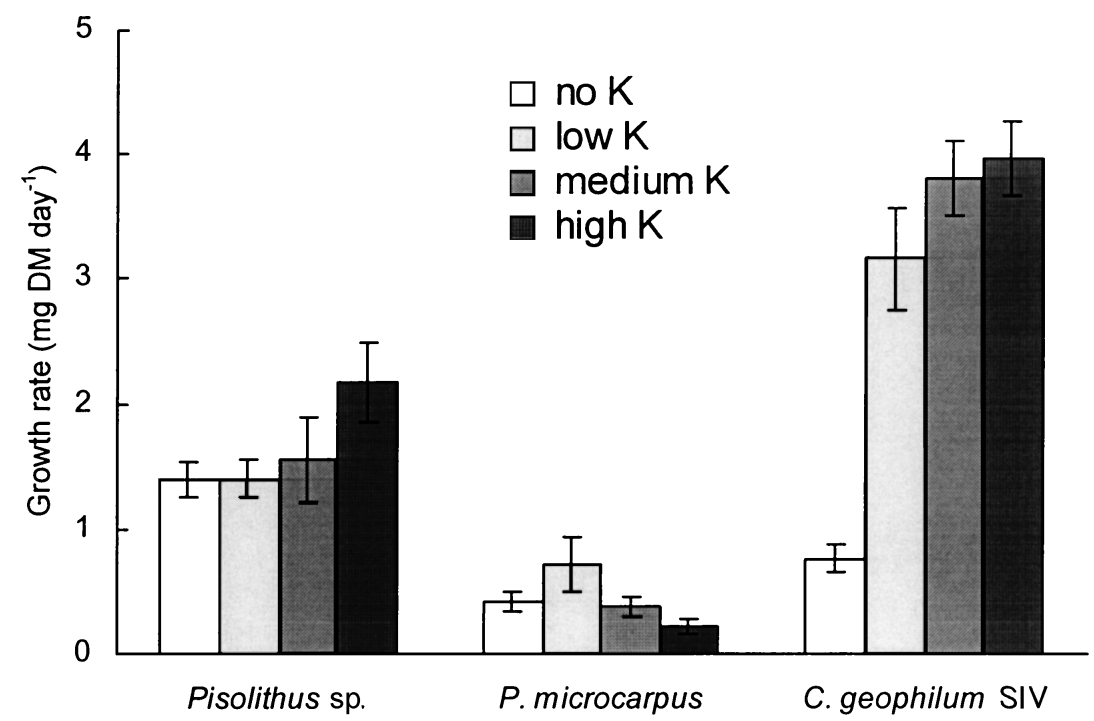

Figure 1. Mean growth rate of the three ectomycorrhizal fungi in liquid medium with different $\mathrm{K}$ concentrations. Bars: S.D. By analysis of variance, the $\mathrm{F}$ ratios for fungal isolate, $\mathrm{K}$ concentration and the interaction term (fungal isolate $\times \mathrm{K}$ concentration) were all highly significant $(P<0.001)$.

fungal N concentration 3.75- to 4.93-fold, with P. tinctorius 2144 showing the largest response and isolate 441 showing the smallest. Fungal $\mathrm{N}$ uptake in the presence of $\mathrm{K}$ followed the sequence: $C$. geophilum $\mathrm{SIV}>P$. microcarpus $>$ Pisolithus sp., but the last two showed similar N uptake at the highest K addition level.

The three fungi also varied significantly in $\mathrm{P}$ concentration and uptake (Fig. 3), both of which were generally highest in Pisolithus sp. Higher P
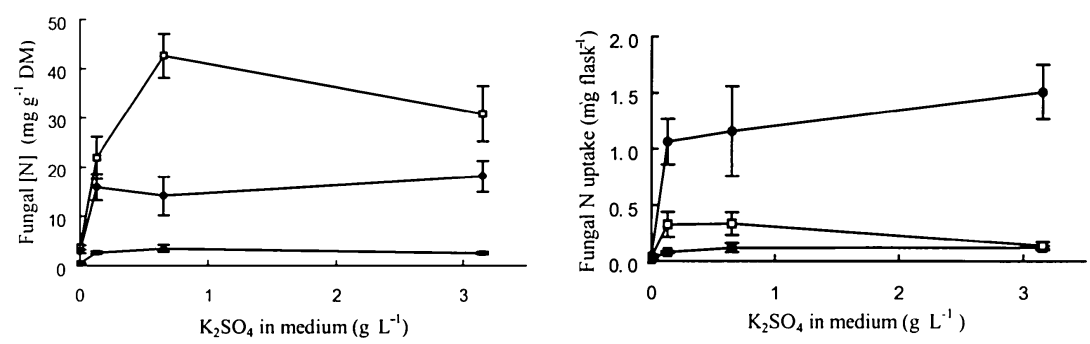

Figure 2. Effects of $\mathrm{K}$ concentration in the culture medium on ectomycorrhizal fungal $\mathrm{N}$ concentration and uptake. $\square$ Pisolithus sp.; $\square$ P. microcarpus; $\bullet$ C. geophilum SIV; bars: standard deviation. 

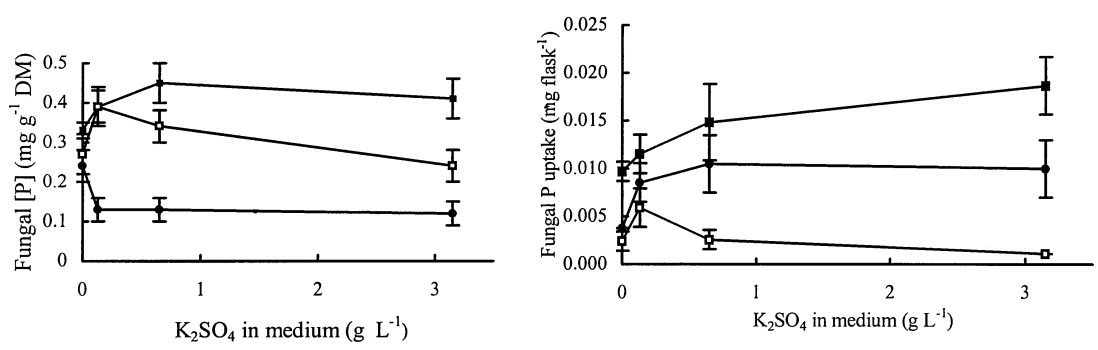

Figure 3. Effects of $\mathrm{K}$ concentration in the culture medium on ectomycorrhizal fungal P concentration and uptake. $\square$ Pisolithus sp.; $\square$ P. microcarpus; $\bullet$ C. geophilum SIV; bars: S.D.

concentrations were observed in $P$. microcarpus than $C$. geophilum $\mathrm{SIV}$, while $\mathrm{P}$ uptake showed the opposite trend. Potassium supplied in the medium led to a pronounced decrease in $\mathrm{P}$ concentrations in $C$. geophilum SIV but an increase in the Pisolithus isolates. The $\mathrm{P}$ concentration in P. microcarpus increased markedly in the low-K medium compared with the K-free control and then decreased as $\mathrm{K}$ concentration in the medium increased. Added $\mathrm{K}$ in the medium enhanced P uptake by both Pisolithus sp. and C. geophilum SIV, but $\mathrm{P}$ uptake by $P$. microcarpus showed an increase in the low-K medium compared with the control and then decreased as $\mathrm{K}$ concentration in the medium increased.

As would be expected, fungal $\mathrm{K}$ concentrations and uptake values were lowest and least variable in the zero-K medium (Fig. 4), with variable responses among the three fungi to increasing $\mathrm{K}$ concentration in the culture medium. Fungal K concentrations changed in the sequence Pisolithus sp. $>$ P. microcarpus $>$ C. geophilum SIV in contrast to K uptake, which followed the sequence Pisolithus sp. $>$ C. geophilum $\mathrm{SIV}>$ P. microcarpus.
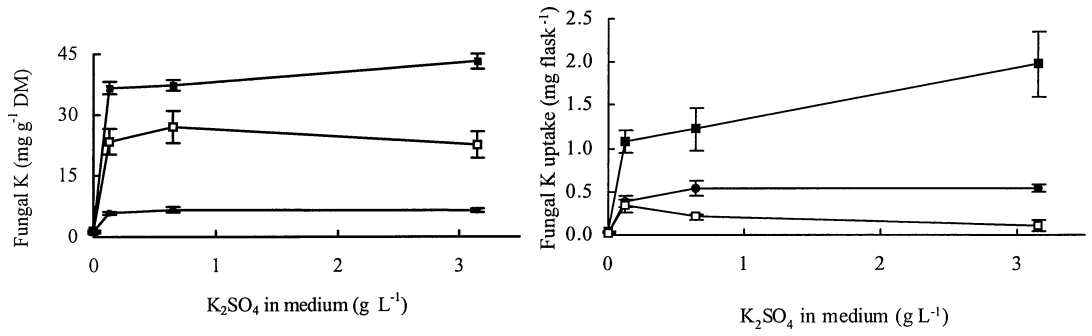

Figure 4. Effects of $\mathrm{K}$ concentration in the culture medium on ectomycorrhizal fungal K concentration and uptake. $\square$ Pisolithus sp.; $\square$ P. microcarpus; $\bullet$ C. geophilum SIV; bars: standard deviation. Bars: S.D. 


\section{Kinetics of Potassium Uptake by Ectomycorrhizal Fungi}

The time-dependent depletion of $\mathrm{K}$ concentration in solutions attributable to the ectomycorrhizal fungi can be expressed by:

$$
C=C_{0}+a e^{-b t}
$$

where $C$ is the $\mathrm{K}$ concentration in solution; $t$ is the time; and $a, b$, and $C_{0}$ are constants (Fig. 5). According to the equation above, as time $t \rightarrow \infty, C=C_{0}$. Therefore, $C_{0}$ could be considered as the minimum K concentration $\left(C_{\min }\right)$ in solution when each fungus initiated net influx and the values derived were 2.12 (Pisolithus sp.), 3.53 (P. microcarpus) and $5.39 \mu \mathrm{mol} \mathrm{L}^{-1}$ (C. geophilum SIV) (Table 1). According to the depletion of $\mathrm{K}$ concentrations in the solutions, the time-dependent $\mathrm{K}$ uptakes ( $\mu \mathrm{mol} \mathrm{g}{ }^{-1} \mathrm{DM}$ ) of the fungi were obtained and are shown in Figure 6. The amount of K taken up followed the sequence Pisolithus sp. $>$ P. microcarpus $>$ C. geophilum SIV.

The rates of $\mathrm{K}$ influx $(I)$, derived from the changes in external concentrations $(C)$, were calculated by the Michaelis-Menten (1974) saturation equation as follows:

$$
I=\frac{I_{\max } C}{K_{m}+C}(\text { Jongbloed et al., 1991; Caassen and Barber, 1974) }
$$

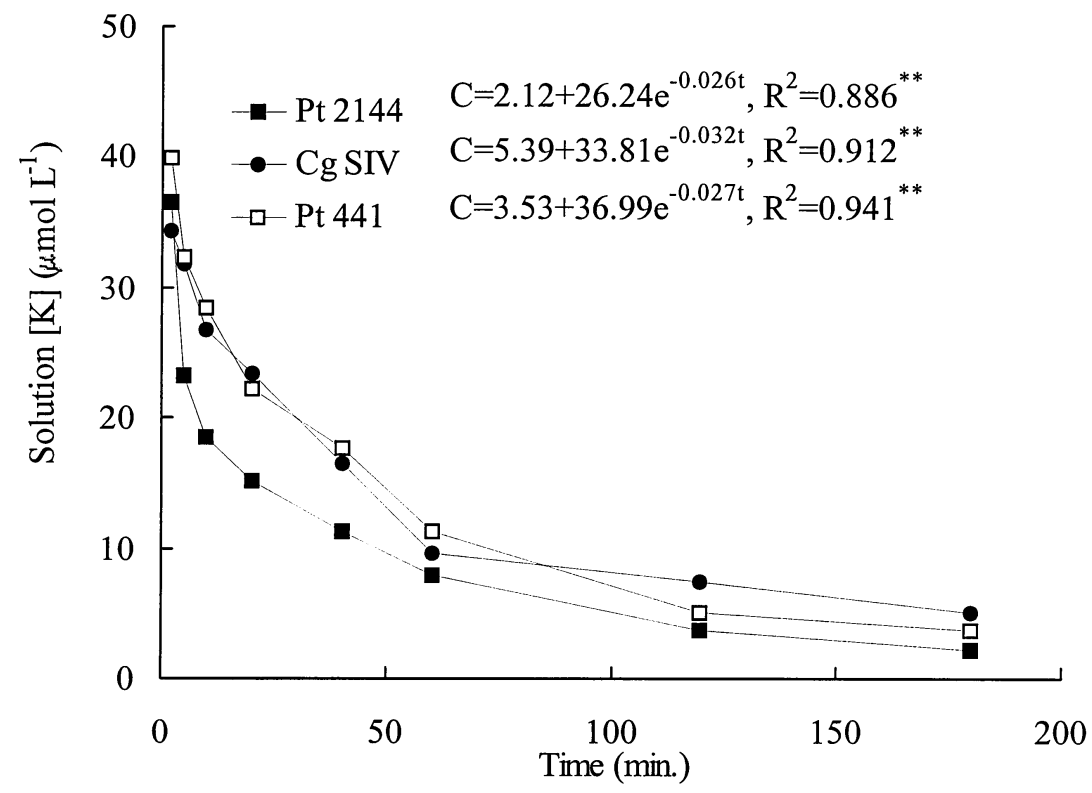

Figure 5. Time-dependent depletion of $\mathrm{K}^{+}$concentration in solutions by the three ectomycorrhizal fungi. Pt2144: Pisolithus sp.; CgSIV: Cenococcum geophilum SIV; Pt441: Pisolithus microcarpus. 
Table 1

Kinetic parameters of $\mathrm{K}$ uptake by the three ectomycorrhizal fungi (mean \pm S.D.)

\begin{tabular}{lrcr}
\hline Fungus & $\begin{array}{c}K_{m} \\
\left(\mu \mathrm{mol} \mathrm{L} \mathrm{L}^{-1}\right)\end{array}$ & $\begin{array}{c}I_{\max } \\
\left(\mu \mathrm{mol} \mathrm{g}^{-1} \mathrm{DM} \cdot \mathrm{h}^{-1}\right)\end{array}$ & $\begin{array}{c}C_{\min } \\
\left(\mu \mathrm{mol} \mathrm{L} \mathrm{L}^{-1}\right)\end{array}$ \\
\hline Pisolithus tinctorius 2144 & $5.47 \pm 3.26$ & $21.63 \pm 5.18$ & $2.12 \pm 0.73$ \\
Pisolithus tinctorius 441 & $5.20 \pm 1.54$ & $9.60 \pm 2.04$ & $3.53 \pm 0.84$ \\
Cenococcum geophilum SIV & $14.85 \pm 5.98$ & $13.14 \pm 4.23$ & $5.39 \pm 0.92$ \\
\hline
\end{tabular}

where $I_{\max }$ is the maximum influx rate when $\mathrm{K}$ in solution does not limit uptake, and $K_{m}$, the Michaelis constant, is the external $\mathrm{K}$ concentration at which the net influx of $\mathrm{K}$ is equal to half of $I_{\max }$. As can be seen from Table 1, the three fungi showed a range of $I_{\max }$ values: 9.60, 13.14 and $21.63 \mu \mathrm{mol} \mathrm{g}{ }^{-1} \mathrm{DM}$ $\mathrm{h}^{-1}$ for P. microcarpus, C. geophilum SIV, and Pisolithus sp., respectively. In contrast, the two Pisolithus isolates exhibited similar $K_{m}$ values, which were much lower than that of $C$. geophilum SIV, and no significant variation was observed in $C_{\min }$ for K uptake by the two Pisolithus strains. Moreover, the $K_{m}$ for K uptake by $C$. geophilum SIV was approximately three times higher than those of the two Pisolithus isolates, which differed little, if at all, in $K_{m}$ value.

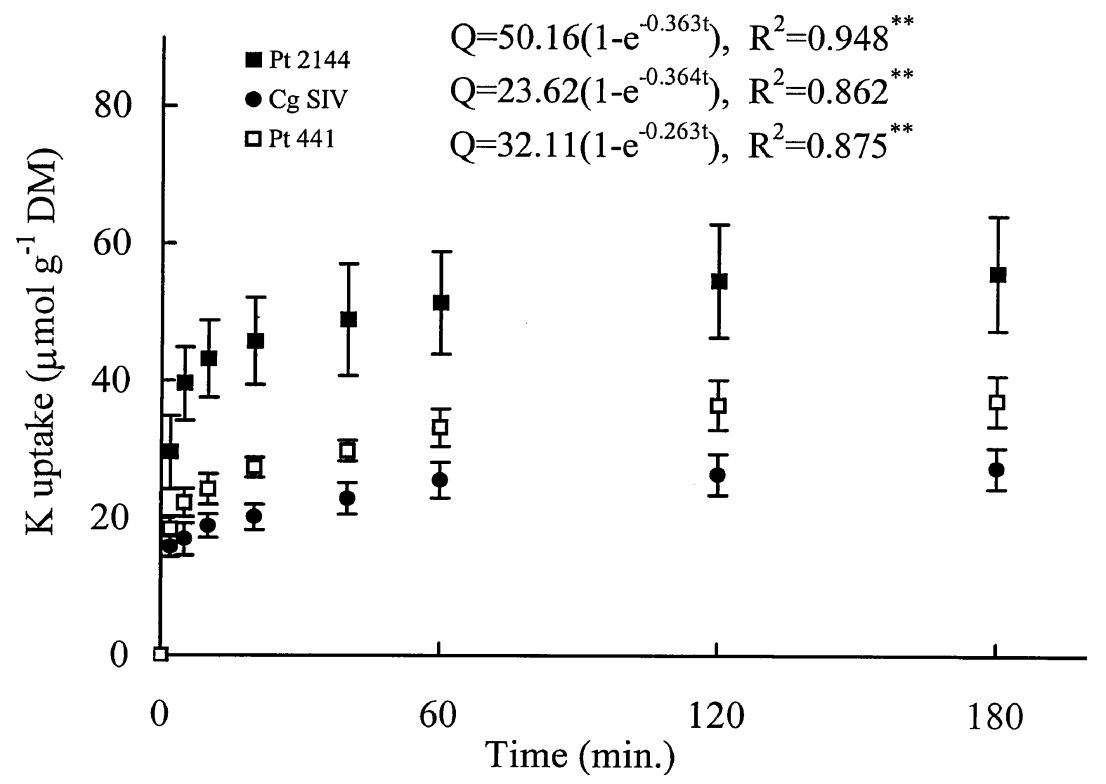

Figure 6. Time-dependent change in $\mathrm{K}$ uptake by the three ectomycorrhizal fungi. Pt2144: Pisolithus sp.; CgSIV: Cenococcum geophilum SIV; Pt441: Pisolithus microcarpus. 


\section{DISCUSSION}

The external hyphae of ectomycorrhizas are responsible for the uptake and subsequent transfer of nutrients to their hosts. In general, good growth and development of hyphae in soils can extend spatially the zone of nutrient extraction from soils. The major impact of mycorrhizal fungi on the area available for nutrient absorption by the seedlings of Pinus taeda was provided by the extraradical hyphae, which led to an increase of approximately 40 -fold in the case of P. tinctorius and 25-fold for C. geophilum in relation to the uncolonized controls (Rousseau et al., 1994). In return, essential nutrients, in particular N and P, influenced the growth of the ectomycorrhizal fungi (Smith and Read, 1997). The development of external hyphae on the root surfaces of Afzelia africana inoculated with four ectomycorrhizal fungi was not related to mineral nutrition (Bâ et al., 1999). However, in forests and plantations, the roots of trees are associated with guilds of large numbers of ectomycorrhizal fungi and relatively few of these may be involved in tree nutrient acquisition in any particular location. There is also very little information available on the effects of $K$ on the growth of mycorrhizal fungi. In the present experiments, $\mathrm{K}$ stress in the culture solution depressed the growth of the ectomycorrhizal fungi, which showed different responses to $\mathrm{K}$ supply. It therefore seems reasonable to suggest that $\mathrm{K}$ in the soil solution would similarly affect the growth of external hyphae and their development on the surfaces of their host roots. The growth of $C$. geophilum SIV was very much poorer in K-free solution than solutions containing $\mathrm{K}$, but there were no differences in the growth of Pisolithus sp. in controls and $\mathrm{K}$-containing solutions except at the highest $\mathrm{K}$ concentration. It is possible that the K-free solutions were contaminated with $\mathrm{K}$ introduced with the mycelial plugs, but we did not determine the K status of the inocula. Nevertheless, the results do indicate that growth and development of mycorrhizal fungi can vary in response to varying $\mathrm{K}$ supply and imply that $\mathrm{K}$ in soil solutions may have less impact on the extraradical hyphae of Pisolithus sp. than of C. geophilum SIV.

Potassium accumulation in the fungi in the first experiment was apparently well correlated with accumulation of P. This may be the result of accumulation of polyphosphate in the fungal cells and is consistent with the findings of Orlovich and Ashford (1993), whose data indicate that in Pisolithus tinctorius, polyphosphate is uniformly distributed in the fungal vacuoles and is stabilized by $\mathrm{K}^{+}$.

There were large variations in the concentrations and uptake values of $\mathrm{N}, \mathrm{P}$, and $\mathrm{K}$ in leaves of ectomycorrhizal Afzelia africana depending on fungal inoculation (Bâ et al., 1999). The concentrations of $\mathrm{K}$ and $\mathrm{P}$ in the leaves of Douglas fir seedlings infected by Laccaria bicolor S238N were increased by approximately $36 \%$ and 55\% over non-mycorrhizal controls (Huang and Lapeyrie, 1996). Smith et al. (1981) observed elevated concentrations of K in shoots of mycorrhizal Trifolium subterraneum when the plants were grown in Pdeficient soils. If sufficient $\mathrm{P}$ was supplied to the soil to remove any mycorrhizal 
growth response, then $\mathrm{K}$ concentrations in both groups of plant were very similar. Fungal $\mathrm{K}$ accumulation is strongly influenced by the form of $\mathrm{N}$ available $\left(\mathrm{NH}_{4}^{+}\right.$vs. $\left.\mathrm{NO}_{3}^{-}\right)$as well as by other ions (Smith and Read, 1997). This suggests that the important role played by mycorrhizal fungi in nutrient uptake is influenced by complex nutrient interactions. Carefully designed experiments to investigate $\mathrm{K}$ nutrition of mycorrhizal fungal isolates and mycorrhizal plants need to take all these potentially confounding factors into account. The fungal concentrations of $\mathrm{N}, \mathrm{P}$, and $\mathrm{K}$ in our experiments changed differently in response to varying $\mathrm{K}$ supply in the culture solution. In general, $\mathrm{K}$ supply promoted increases in the concentrations of $\mathrm{N}$ and $\mathrm{K}$ in the different ectomycorrhizal fungi to different extents, while $\mathrm{P}$ concentrations increased in one fungus (Pisolithus sp.) and decreased in another (C. geophilum SIV). These results support earlier reports of complex interactions in nutrient uptake by ectomycorrhizal fungi.

Potassium transporters in plants and fungi have received much attention (Rodriguez-Navarro, 2000). The process is complicated by the fact that both the surface potential and the membrane potential influence the apparent affinity of the ion for the carrier. The kinetic parameters of $\mathrm{K}$ influx depend upon cellular $\mathrm{pH}$ and $\mathrm{K}$ concentrations (Boxman and Roelofs, 1988). The fungi were, therefore, pre-cultured in buffer solution to avoid interferences from cellular $\mathrm{pH}$ before determining the kinetic parameters of $\mathrm{K}$ influx in the present experiments. The $\mathrm{K}$ influx rates of all three fungi from external concentrations satisfied Michaelis-Menten kinetics and support the hypothesis of active influx (Kuhn et al., 2000). The results support the hypothesis that mycorrhizal fungi may show quite small $C_{\min }$ values for $\mathrm{K}$ influx, ranging from 2.12 to $5.39 \mu \mathrm{mol}$ $\mathrm{L}^{-1}$, in relation to $\mathrm{K}$ concentrations in soil solutions. Such low $C_{\text {min }}$ values could allow the external hyphae of mycorrhizas to extract $\mathrm{K}$ efficiently from K-deficient soils. Furthermore, the ectomycorrhizal fungi exhibited $K_{m}$ values ranging from 5.20 to $14.85 \mu \mathrm{mol} \mathrm{L}{ }^{-1}$ for $\mathrm{K}$ influx, indicating high affinities of $\mathrm{K}$ carriers. However, soil solutions consist of complex ions and an appreciable inhibition by these ions of $\mathrm{K}$ influx into mycorrhizal hyphae might be expected in field conditions. It may be of interest that two strains of Pisolithus showed similar $C_{\min }$ and $K_{m}$ values (and therefore perhaps efficiencies and affinities of K carriers) that differed from those of $C$. geophilum despite the large geographical distances between the locations where the Pisolithus strains were originally isolated.

$I_{\max }$ for K uptake by the three fungi varied widely. Glass (1976) proposed that $\mathrm{K}$ influx into plant roots was regulated via allosteric inhibition of the $\mathrm{K}$ carrier by internal $\mathrm{K}$ concentrations, resulting in changes in kinetic parameters, especially $I_{\max }$ reduction at high cellular K concentrations. Similar effects of cellular $\mathrm{K}$ on kinetic parameters for $\mathrm{K}$ influx have also been observed in cereal crops. However, it is not certain whether this is also true for ectomycorrhizal fungi. In Experiment 1, the mycorrhizal fungi varied significantly in K concentrations even in the medium with a low K concentration $(20 \%$ of "normal" $\mathrm{K}$ concentration). We can therefore suggest that the mycorrhizal fungi used 
for determining kinetic parameters (cultured in medium with $90 \%$ of the $\mathrm{K}$ omitted) could have variable $\mathrm{K}$ concentrations. We must, therefore, be cautious in interpreting differences in $I_{\max }$ for $\mathrm{K}$ influx for the three fungi studied as differences in the properties of $\mathrm{K}$ carriers.

Potassium nutrition of ectomycorrhizal fungi in association with host trees still remains unclear. Fungal isolates cultured under well-controlled conditions are usually employed to avoid interferences in the field and to simplify the experimental methods. The results obtained from such studies are valuable but could differ from plant-fungus associations in the field. These potential differences must be taken into consideration in the interpretation of data from fungal cultures.

\section{ACKNOWLEDGMENTS}

This work was funded by the Natural Science Foundation of China (Project 39970139), the Chinese Ministry of Science and Technology (Project 2002BA516A17-05) and the Royal Society of London (Projects Q736 and 15360).

\section{REFERENCES}

Bâ, A. M., K. B. Sanon, R. Duponnois, and J. Dexheimer. 1999. Growth response of Afzelia africana Sm. seedlings to ectomycorrhizal inoculation in a nutrient-deficient soil. Mycorrhiza 9: 91-95.

Borst-Pauwels, G. W. F. H. 1981. Ion transport in yeast. Biochemistry and Biophysics Acta 650: 88-127.

Bowen, G. D. 1973. Mineral nutrition of ectomycorrhizae. In Ectomycorrhizae: Their ecology and physiology, eds. G. C. Marks, T. T. Kozlowski, 151-205. New York: Academic Press.

Boxman, A. W., and J. G. M. Roelofs. 1988. Some effects of nitrate versus ammonium nutrition on the nutrient fluxes in Pinus sylvestris seedlings: Effects of mycorrhizal infection. Canadian Journal of Botany 66: 10911097.

Bucking, H., and W. Heyser. 2000. Subcellular compartmentation of elements in non-mycorrhizal and mycorrhizal roots of Pinus sylvestris: An $\mathrm{x}$-ray microanalytical study. II. The distribution of calcium, potassium and sodium. New Phytologist 145: 321-331.

Caassen, N., and S. A. Barber. 1974. Simulation model for nutrient uptake from soil by a growing plant root system. Agronomy Journal 68: 961-964.

Chalot, M., A. Javelle, D. Blaudez, R. Lambilliote, R. Cooke, H. Sentenac, D. Wipf, and D. Botton. 2002. An update on nutrient transport processes in ectomycorrhizas. Plant and Soil 244: 165-175.

Glass, A. D. M. 1976. Regulation of potassium absorption by barley roots: An allosteric model. Plant Physiol. 58: 33-37. 
Huang, J. G., and F. Lapeyrie. 1996: Ability of ectomycorrhizal fungus Laccaria bicolor $\mathrm{S} 238 \mathrm{~N}$ to increase the growth of Douglas fir seedlings and their phosphorus and potassium uptake. Pedosphere 6: 217224.

Jentschke, G., B. Brandes, A. J. Kuhn, W. H. Schröder, and D. L. Godbold. 2001. Interdependence of phosphorus, nitrogen, potassium and magnesium translocation by the ectomycorrhizal fungus Paxillus involutus. New Phytologist 149: 327-337.

Jongbloed, R. H., J. M. A. M. Clement, and G. W. F. H. Borst-Pauwels. 1991. Kinetics of $\mathrm{NH}_{4}^{+}$and $\mathrm{K}^{+}$uptake by ectomycorrhizal fungi: Effect of $\mathrm{NH}_{4}^{+}$ on $\mathrm{K}^{+}$uptake. Physiologia Plantarum 83: 427-432.

Kuhn, A. J., W. H. Schröder, and J. Bauch. 2000. The kinetics of calcium and magnesium entry into mycorrhizal spruce roots. Planta 210: 488496.

Landeweert, R., E. Hoffland, R. D. Finlay, T. W. Kuyper, and N. van Breemen. 2002. Linking plants to rocks: Ectomycorrhizal fungi mobilize nutrients from minerals. Trends of Ecological Evolution 16: 248-254.

Lapeyrie, F. 1988. Oxalate synthesis from soil bicarbonate by the mycorrhizal fungus Paxillus involutus. Plant and Soil 110: 3-8.

Lapeyrie, F., G. A. Chilvers, and C. A. Bhem. 1987. Oxalic acid synthesis by the mycorrhizal fungus Paxillus involutus (Botsch. ex Fr.) Fr. New Phytologist 106: 139-146.

Marschner, H. 1995. Mineral nutrition of higher plants, 2nd ed., 537-595. London: Academic Press.

Martin, F., J. Díez, B. Dell, and C. Delaruelle. 2002. Phylogeography of the ectomycorrhizal Pisolithus species as inferred from nuclear ribosomal DNA ITS sequences. New Phytologist 153: 345-357.

Orlovich, D. A., and A. E. Ashford. 1993. Polyphosphate granules are an artifact of specimen preparation in the ectomycorrhizal fungus Pisolithus tinctorius. Protoplasma 173: 91-102.

Paris, F., P. Bonnaud, J. Ranger, and F. Lapeyrie. 1995. In vitro weathering of phlogopite by ectomycorrhizal fungi. I. Effect of $\mathrm{K}^{+}$and $\mathrm{Mg}^{2+}$ deficiency on phyllosilicate evolution. Plant and Soil 177: 191-201.

Paris, F., B. Botton, and F. Lapeyrie. 1996. In vitro weathering of phlogopite by ectomycorrhizal fungi. II. Effect of $\mathrm{K}^{+}$and $\mathrm{Mg}^{2+}$ deficiency and $\mathrm{N}$ sources on accumulation of oxalate and $\mathrm{H}^{+}$. Plant and Soil 179: 141150.

Rodriguez-Navarro, A. 2000. Potassium transport in fungi and plants. Biochemistry and Biophysics Acta - Rev. Biomembranes 1469: 1-30.

Rousseau, J. V. D., D. M. Sylvia, and A. J. Fox. 1994. Contribution of ectomycorrhiza to the potential nutrient-absorbing surface of pine. New Phytologist 128: 639-644.

Smith, S. E., and D. J. Read. 1997. Mycorrhizal symbiosis, 2nd ed. London: Academic Press. 
Smith, S. E., F. A. Smith, and D. J. D. Nicholas. 1981. Effects of endomycorrhizal infection on phosphate and cation uptake by Trifolium subterraneum. Plant and Soil 63: 57-64.

Wallander, H. 2000. Use of strontium isotopes and foliar K content to estimate weathering of biotite induced by pine seedlings colonised by ectomycorrhizal fungi from two different soils. Plant and Soil 222: 215-229.

Wallander, H., and T. Wickman. 1999. Biotite and microcline as potassium sources in ectomycorrhizal and non-mycorrhizal Pinus sylvestris seedlings. Mycorrhiza 9: 25-32. 